\title{
Role of endoscopic ultrasonography with and without fine needle aspiration cytology in the diagnosis and staging of lymphoma
}

\author{
Noemí Hernández Álvarez-Buylla, Antonio Z Gimeno García, Juan Adolfo Ortega Sánchez, \\ Enrique Quintero
}

Servicio de Aparato Digestivo, Hospital Universitario de Canarias, La Laguna, Tenerife, Spain

Correspondence: Antonio Z Gimeno-García. Address: Hospital Universitario de Canarias. Unidad de Endoscopia (10ā planta), Departamento de Gastroenterología, La Laguna, Tenerife, Spain. Telephone: 34-922-678-554. Fax: 34-922-

678-554. E-mail: antozeben@gmail.com

Received: May 18, 2012

DOI : $10.5430 / j h m . v 2 n 3 p 55$
Accepted: June 27, 2012

Published: September 1, 2012

URL: http://dx.doi.org/10.5430/jhm.v2n3p55

\begin{abstract}
Diagnosis of lymphoma is frequently challenging. The complexity of the sub-classification of lymphomas along with the necessity of a high quality sample leads to costly and invasive procedures in order to achieve the correct diagnosis. Endoscopic ultrasound is a valuable tool for the diagnosis and staging of gastrointestinal neoplasms as well as those that involve structures in the vicinity of the digestive tract. Whereas most gastrointestinal lymphomas are diagnosed and sub-classified using endoscopic biopsies, those involving deep-seated organs or lymph nodes might be targeted by minimal invasive procedures as endoscopic ultrasound-guided fine needle aspiration cytology. Endoscopic ultrasound is also an accurate tool for the local staging of gastrointestinal lymphomas and prediction of the response to Helicobacter pylori eradication. This review summarizes the indications and evidence of endoscopic ultrasonography with or without fine needle aspiration cytology in the diagnosis and staging of lymphoma.
\end{abstract}

\section{Key words}

Endoscopic ultrasonography, Lymphoma, Fine needle aspiration cytology

\section{I ntroduction}

Diagnosis of lymphoma is a clinical challenge. Whereas the diagnosis of gastrointestinal lymphomas is straight forward by taking multiple endoscopic biopsies ${ }^{[1]}$, the diagnosis of deep-seated nodal or primary organ lymphoma is often difficult or risky if percutaneous imaging techniques such as ultrasound (U.S.) or computed tomography (CT) are used ${ }^{[2,3]}$. In fact, most of them are diagnosed using invasive and expensive procedures such as thoracotomy, laparotomy, laparoscopy or mediastinoscopy. In addition, lymphoma classification has increased its complexity in recent years with the development of molecular and immunohistochemical techniques. The recent classification of the World Health Organization (WHO) ${ }^{[4]}$ provides 70 different forms of lymphoma. An accurate diagnosis and classification is critical as prognosis and treatment of lymphomas change depending on the stage of disease and histopathological classification. In order to achieve this goal, high quality samples are usually required ${ }^{[5,6]}$. 
Gastrointestinal lymphomas are the most frequent primary extranodal lymphomas. Endoscopic ultrasound (EUS) is a technique that combines conventional endoscopic and ultrasound image. The proximity of the ultrasound transducer to the gastrointestinal wall and neighboring organs makes it an ideal tool for staging gastrointestinal wall lesions, and evaluation of deep-seated abdominal nodes or organs inaccessible by other techniques. In addition, EUS allows fine needle aspiration cytology (EUS-FNA) or biopsy (EUS-B) providing cytological or histological samples of good quality for the diagnosis of different types of lesions ${ }^{[7,8]}$. Ancillary techniques such as flow cytometry (FC) or immunohistochemistry can be performed on EUS-FNA samples improving diagnostic yield ${ }^{[9]}$. EUS has several advantages over other imaging techniques such as real-time sampling, low risk of complications because of its proximity to the gastrointestinal wall (i.e. perforation, bleeding and seeding) and sampling of small lesions ${ }^{[10]}$.

This review focuses on the applications of EUS in extranodal lymphomas (gastrointestinal, pancreatic and splenic) as well as in nodal lymphoma.

\section{Primary extranodal lymphomas}

Primary extranodal lymphomas constitute $25-35 \%$ of the non-Hodgkin lymphoma (NHL) ${ }^{[11,12]}$. The digestive tract is the most common site (35-50\%) of the primary extranodal lymphoma ${ }^{[13,14]}$. In primary lymphomas of the digestive tract $60 \%$ of cases involve the stomach.

\subsection{Gastrointestinal lymphomas}

Gastrointestinal lymphomas constitute the majority of extranodal lymphomas. Overall, primary gastric lymphomas constitute 70\%, followed by small bowel, colon and rectal lymphomas ${ }^{[15]}$, MALT lymphoma (mucosa-associated lymphoid tissue) and diffuse large B cell lymphoma (DLBCL) are the most frequent. Other lymphomas such as mantle lymphomas, follicular lymphomas or peripheral T-cell lymphomas are more rarely found. The diagnosis and classification of gastrointestinal lymphomas are usually achieved by large endoscopic biopsies (jumbo biopsies, snare biopsies or biopsies within biopsies). Once diagnosed and classified, the next step is staging the tumor. EUS is the best imaging technique to assess the gastrointestinal wall. It makes possible to distinguish the different layers and it is considered the technique of choice for staging of esophageal or gastric tumors ${ }^{[16]}$. Although EUS is able to stage the tumor infiltration in DLBCL, it has a low impact in this tumor as it does not really change the clinical management.

Unlike DLBCL, EUS is particularly useful in the evaluation of MALT lymphoma ${ }^{[17]}$. Over $90 \%$ of MALT lymphomas are associated with Helicobacter pylori infection and several studies show that in early stages (mucosal or submucosal involvement), the disease heals after treatment ${ }^{[18-20]}$. On the other hand, in advanced stages the treatment of choice is chemotherapy or immunotherapy. EUS imaging is not specific of MALT lymphoma and therefore it has no diagnostic value. However, EUS is extremely accurate in differentiating early invasion (T1 mucosal or submucosal, EI1 of Ann Arbor classification) from T2-T4 (EI2) or TxN1 (EII1) ${ }^{[21]}$. Diagnostic accuracy for T staging has ranged between $80 \%$ and $90 \%$ across the studies ${ }^{[22,23]}$, whereas for $\mathrm{N}$ stage, it ranges between $71 \%$ and $90 \%{ }^{[22,24]}$. Accuracy is even higher when EUS is associated with FNA and FC being reported as high as $97 \%{ }^{[25]}$. Another indication is the prognostic value of EUS. Tumoral infiltration assessed by EUS correlates with tumoral healing after Helicobacter pylori treatment, so, it is not surprising the great EUS value for predicting response to therapy. Thus, different studies agree that when wall involvement assessed by EUS is superficial (mucosal or submucosal), the chance of healing after eradication therapy is more than $75 \%{ }^{[18,26,27]}$.

Some authors found a high correlation between histological improvement and normalization of the gastric wall evaluated by endoscopic ultrasound ${ }^{[17,28,29]}$, supporting its usefulness in surveillance after treatment. However, in other reports that correlation was much lower ranging from $33 \%$ and $54 \%{ }^{[30,31]}$. Therefore, at present, EUS cannot be recommended for MALT lymphoma surveillance after treatment, and biopsies remain the only reliable proof of residual disease. Finally, EUS-FNA makes sampling possible of either regional lymph nodes or in the rare cases with thickened gastric folds in 
which endoscopic biopsy results negative for malignancy ${ }^{[32]}$. The use of large FNA needles (19 gauge) provides histological samples, useful for ancillary techniques such as immunohistochemistry or FC ${ }^{[33]}$.

\subsection{Pancreatic lymphoma}

Less than $0.5 \%$ of pancreatic tumors are primary pancreatic lymphomas (PPL) ${ }^{[15]}$. Although almost $30 \%$ of non-Hodgkin lymphomas involve the pancreatic gland, less than $1 \%$ are considered PPL ${ }^{[34]}$. However, despite its rarity, to achieve a correct diagnosis of this disease is crucial as the prognosis and the management of PPL compared with the much more frequent pancreatic adenocarcinoma is completely different. The diagnostic criteria for PPL include ${ }^{[35]}: 1$ ) mass which predominantly affects the pancreas, 2) peripancreatic node involvement, 3) absence of palpable lymph nodes, 4) absence of mediastinal involvement, 5) absence of hepatosplenic dissemination, 6) blood cell differential count normal.

The diagnosis of this disease is challenging. EUS is an ideal technique to evaluate the pancreatic gland because of the proximity of the gastric wall and duodenum and safety. EUS pattern has been described as a "strongly hypoecogenic appearance in the pancreas, hypertrophy in all its segments, a hyperechoic wall in the common pancreatic duct and multiple isoechogenic pancreatic nodes” ${ }^{[36,37]}$. However, this pattern is not specific enough to differentiate PPL from other solid pancreatic masses. When suspected, a cytological or histological sample is needed in order to prescribe a proper treatment ${ }^{[9]}$. Only one study evaluated the diagnostic utility of EUS-FNA in the diagnosis of PPL ${ }^{[2]}$. This case series included 14 patients with final diagnosis of PPL who underwent EUS-FNA. The authors evaluated the diagnostic yield of cytology alone versus the combination of cytology and FC. The final diagnosis of lymphoma was improved from $30.8 \%$ to $84.6 \%$ when the combination of techniques was used. Furthermore, the FC sub-classification of lymphoma was possible in all the diagnosed cases. Several case reports using EUS-FNA for PPL have also been published ${ }^{[36,37]}$.

\subsection{Splenic lymphoma}

Lymphoma is one of the most common causes of splenic focal masses. Other lesions include metastases, tuberculosis, sarcoidosis, abscesses or infarction ${ }^{[38]}$. Although these lesions can be diagnosed by percutaneous biopsy, it may increase the risk of complications, because the spleen is surrounded by structures such as lung, left kidney and colon. A multicenter Italian study evaluated the efficacy and safety of percutaneous puncture of splenic injuries in 398 patients ${ }^{[3]}$. Lymphoma was the most frequent diagnosis and the diagnostic accuracy by cytology and histology was similar (88.4\% and $88.3 \%$ respectively). It is worth pointing out that the incidence of major complications was $5.3 \%$, which included hemoperitoneum, pneumothorax, subcapsular hematoma and subacute hemorrhage.

Table 1. EUS-FNA in splenic lymphoma

\begin{tabular}{|c|c|c|c|c|c|c|c|}
\hline Author & $\begin{array}{l}\text { Patients } \\
\text { (n) }\end{array}$ & Design & $\begin{array}{l}\text { Needle } \\
\text { size }\end{array}$ & Technique & $\begin{array}{l}\text { Yield } \\
\text { n, (\%) }\end{array}$ & $\begin{array}{l}\text { Sub-typing } \\
\text { yield } \\
\text { n, (\%) }\end{array}$ & Pasess $\dagger$ \\
\hline $\begin{array}{l}\text { Fritscher-Ravens, } \\
\text { et al }\end{array}$ & $12(3)$ & Prospective & $22 \mathrm{G}$ & Cytology & 2/3 (66.6) & 2/3 (66.6) & $2(1-4)$ \\
\hline Eloubeidi, et al & $6(3)$ & Prospective & $22 \mathrm{G}$ & $\begin{array}{l}\text { Cytology } \\
\text { Flow citometry }\end{array}$ & 2/3 (66.6) & 2/3 (66.6) & $4(4-5)$ \\
\hline Iwashita, et al & $5(2)$ & Prospective & $19 \mathrm{G}$ & $\begin{array}{l}\text { Cytology } \\
\text { Flow Citometry } \\
\text { Cytogenetic analysis } \\
\text { Immunohistochemistry }\end{array}$ & $2 / 2(100)$ & $2 / 2)(100)$ & $2(2-3)$ \\
\hline
\end{tabular}

$\dagger$ Median and range

Three case series have evaluated the usefulness of EUS-FNA in focal splenic lesions including a total of 23 patients (Table 1$)^{[38-40]}$. The diagnosis of lymphoma was correctly established in $75 \%$ of cases. In addition, sub-classification was possible in all of them. There were no major complications. 


\section{Nodal lymphomas}

Histological evaluation is the gold standard for final diagnosis of lymphoma ${ }^{[4]}$, whereas the value of cytology is controversial. Some authors claim that the use of cytologic examination combined with FC could obviate more invasive procedures for the study of this disease ${ }^{[41-43]}$. Cytology combined with FC is especially useful at differentiating reactive B from monoclonal B cell neoplasms and therefore in many centers these techniques are used as the initial study for suspected nodal lymphoma ${ }^{[44]}$. Several studies demonstrate the efficacy of cytology in the diagnosis of nodal lymphomas. In the studies using a percutaneous approach, sensitivity and diagnostic accuracy ranged from $66 \%-90 \%$ and $80 \%-60 \%$ respectively ${ }^{[45-47]}$. FC may also be helpful in the immunological sub-typing of nodal lymphoma. Several studies have used EUS-FNA in combination with the FC for the diagnosis of nodal lymphoma (Table 2); all of them with a retrospective design ${ }^{[32,42,48-52]}$. FC significantly increased sensitivity (72.7\% to 100\%) and specificity (93\% to $\left.100 \%\right)$ for the diagnosis of lymphoma compare with the cytomorphologic assessment alone (sensitivity and specificity of $30.8 \%$ to $87 \%$ and $0 \%$ to $100 \%$, respectively). Limitations of FC include the difficulties in the diagnosis of T cell lymphomas because they express some markers typically found in mature T lymphocytes and Hodgkin lymphoma, due to the rarity of the Reed-Steinberg cells in cytology specimens and the absence of monoclonality ${ }^{[53,54]}$. Obtaining histological samples by EUS can solve these problems. Currently, large-caliber FNA needles (19 gauge) are available. These needles provide a larger sample adequate for histological analysis. This issue has been evaluated in several studies, in which histological specimens obtained by EUS were used for immunological sub-typing of lymphoma ${ }^{[33,39,55-57]}$. Overall, 240 patients were included in these studies. In general, a large FNA needle was used (Quick Core TM needle. Cook Endoscopy, Winston Salem, NC. Or 19 gauge needle cytology) and cytomorphologic assessment as well as ancillary techniques (FC and immunohistochemistry) were performed. The diagnosis of lymphoma was achieved in $94 \%$ of the cases and sub-typing according to WHO classification in $85 \%$. Yasuda, et al., ${ }^{[54]}$ reported a success rate of $85.7 \%$ in the grading of follicular centre cell lymphoma. In 29 cases sub-classification was not possible. False-negative results were attributed to significant tumor necrosis ${ }^{[56]}$, insufficient sample ${ }^{[57]}$, and technical limitations related to the type of needle or needle size (Quick Core ${ }^{\mathrm{TM}}$ needle. Cook Endoscopy Inc, Limerick, Ireland) ${ }^{[56]}$.

Table 2. Diagnostic Yield of EUS-FNA with or without ancillary techniques

\begin{tabular}{|c|c|c|c|c|c|c|}
\hline $\begin{array}{l}\text { Author } \\
\text { (yr) }\end{array}$ & $\begin{array}{l}\text { Patients } \\
\text { or lesions } \\
\text { N (N- lymphomas) }\end{array}$ & Design & $\begin{array}{l}\text { Needle } \\
\text { type }\end{array}$ & $\begin{array}{l}\text { Passes } \\
\text { (median) }\end{array}$ & $\begin{array}{l}\text { Cytology } \\
\text { Yield } \\
(\%)\end{array}$ & $\begin{array}{l}\text { Cytology and ancillary } \\
\text { techniques yield } \\
(\%)\end{array}$ \\
\hline \multirow[t]{2}{*}{ Ribeiro, et al* } & \multirow{2}{*}{$38(23)$} & \multirow{2}{*}{ Retrospective } & \multirow{2}{*}{$22 \mathrm{G}$} & \multirow{2}{*}{$\mathrm{NR}^{* *}$} & $S=44$ & $S=74$ \\
\hline & & & & & $E=90$ & $E=93$ \\
\hline \multirow[t]{2}{*}{ Stelow, et al.*¥ } & \multirow{2}{*}{$12(8)$} & \multirow{2}{*}{ Retrospective } & \multirow{2}{*}{$21 / 25 \mathrm{G}$} & \multirow{2}{*}{$2.2 \pm 2.4$} & $S=50$ & $\mathrm{~S}=87.5$ \\
\hline & & & & & $E=100$ & $E=100$ \\
\hline \multirow[t]{2}{*}{ Mehra, et al.* } & \multirow{2}{*}{31 (11) } & \multirow{2}{*}{ Retrospective } & \multirow{2}{*}{$22 \mathrm{G}$} & \multirow{2}{*}{$3(1-7)$} & \multirow{2}{*}{ NR } & $S=72.7$ \\
\hline & & & & & & $E=100$ \\
\hline \multirow{2}{*}{ Pugh, et al.*† } & \multirow{2}{*}{385 (13) } & \multirow{2}{*}{ Retrospective } & \multirow{2}{*}{$22 \mathrm{G}$} & \multirow{2}{*}{ NR } & \multirow{2}{*}{ NR } & $S=92.3$ \\
\hline & & & & & & $E=100$ \\
\hline \multirow{2}{*}{ Al-Haddad, et al.* } & \multirow{2}{*}{$54(38)$} & \multirow{2}{*}{ Retrospective } & \multirow{2}{*}{$22 \mathrm{G}$} & \multirow{2}{*}{$4.9(1-13)$} & $S=87$ & $S=87$ \\
\hline & & & & & $E=50$ & $E=93$ \\
\hline \multirow{2}{*}{ Miletic, et al.* } & \multirow{2}{*}{$16(7)$} & \multirow{2}{*}{ Retrospective } & \multirow{2}{*}{$22 \mathrm{G}$} & \multirow{2}{*}{ NR } & $S=100$ & $S=100$ \\
\hline & & & & & $E=88.8$ & $E=100$ \\
\hline \multirow{2}{*}{ Stacchini, et al.*† } & \multirow{2}{*}{$56(11)$} & \multirow{2}{*}{ Retrospective } & $19 / 22 / 25$ & \multirow{2}{*}{$4.5(3-6)$} & \multirow{2}{*}{ NR } & $S=100$ \\
\hline & & & & & & $E=100$ \\
\hline
\end{tabular}

* Use of Flow citometry as ancillary technique

** Not reported

† Use of immunocytochemistry

$\ddagger$ Use of cytogenetic analysis 
Only 7 complications were reported (2.9\%): 3 cases of submucosal hematoma, 1 case of mild abdominal pain, 2 cases of fever after the procedure. $(39,55-57)$ One patient with cirrhosis died from variceal bleeding, probably not related to the procedure ${ }^{[56]}$.

Another useful technique in this setting is the assessment of cytogenetic abnormalities. Several lymphomas have characteristic genetic abnormalities with a prognostic value and can be helpful in the differential diagnosis. They include specific chromosomal translocations in: follicular lymphoma, mantle cell lymphoma, anaplastic large cell lym-phoma, Burkitt lymphoma, and MALT. A recent study, using percutaneous FNA assessed the sensitivity of fluorescence in situ hybridization (FISH) in lymphoma sub-typing ${ }^{[58]}$. FISH was successful in $95.3 \%$ of the cases and sub-typing was possible in $61.6 \%$. Moreover, this technique changed the final diagnosis in $10 \%$ of the cases.

Regarding EUS-FNA, karyotyping has been rarely performed ${ }^{[32,38,47]}$. In the largest series ${ }^{[55]}, 240$ patients with suspected lymphoma were included. Finally, 152 were diagnosed of lymphoma. Karyotyping was assessed by conventional G-band karyotype analysis. Specific cytogenetic abnormalities were detected in 43 patients, whereas in 188, cell proliferation was insufficient during cell culture. Sensitivity for cytogenetic analysis was only 13.8\%. The authors suggested FISH as an alternative procedure in order to improve the sensitivity of cytogenetic assessment.

\section{Conclusion}

Endoscopic ultrasound is a useful tool for locoregional staging of MALT lymphoma, as well as a good predictor of response to eradication therapy. In addition, EUS-FNA is a useful technique in patients with suspected lymphoma located in organs whose puncture by other techniques is difficult because of their access or it can be of a high risk for the patient, as is the case of the pancreatic gland or spleen. Besides the technological development in this field makes it possible to obtain histological samples often complex and can avoid the use of more invasive diagnostic procedures.

\section{Conflict of interests}

The authors declare that no competing interests exist.

\section{References}

[1] Fischbach W, Dragosics B, Kolve-Goebeler ME, Ohmann C, Greiner A, Yang Q, et al. Primary gastric B-cell lymphoma: results of a Multicenter prospective study. The German-Austrian Gastrointestinal Lymphoma Study Group. Gastroenterology. 2000; 119: 1191-202. PMid:11054376

[2] Khashab M, Mokadem M, DeWitt J, Emerson R, Sherman S, LeBlanc J, et al. Endoscopic ultrasound-guided fine-needle aspiration With or Without flow cytometry for the diagnosis of primary pancreatic lymphoma - a case series. Endoscopy. 2010; 42: 228-31. PMid:20101569 http://dx.doi.org/10.1055/s-0029-1243859

[3] Civardi G, Vallisa D, Berte R, Giorgio A, Filice C, Caremani M, et al. Ultrasound-guided fine needle biopsy of the spleen: high clinical Efficacy and Low Risk in a Multicenter Italian study. Am J Hematol. 2001; 67: 93-9. PMid:11343380 http://dx.doi.org/10.1002/ajh.1085

[4] Swerdlow, SH, Campo E, Harris NL, Jaffe ES, Pileri SA, Stein H, et al. (Eds). WHO Classification of Tumours of Haematopoietic and Lymphoid Tissues, 4th edn. IARC Press: Lyon, 2008.

[5] Kwan V, Gottlieb D. Endoscopic ultrasound-fine needle aspiration for the diagnosis of lymphoma: are we there yet? J Gastroenterol Hepatol. 2009; 24: 1808-9. PMid:20002939 http://dx.doi.org/10.1111/j.1440-1746.2009.06137.x

[6] Armitage JO. How I treat Patients with diffuse large B-cell lymphoma. Blood. 2007; 110: 29-36. PMid:17360935 http://dx.doi.org/10.1182/blood-2007-01-041871

[7] Nguyen P, Feng JC, Chang KJ. Endoscopic ultrasound (EUS) and EUS-guided fine-needle aspiration (FNA) of liver lesions. Gastrointest Endosc. 1999; 50: 357-61. PMid:10462656 http://dx.doi.org/10.1053/ge.1999.v50.97208 
[8] Crowe DR, Eloubeidi MA, Chhieng DC, Jhala NC, Jhala D, Eltoum IA. Fine-needle aspiration biopsy of hepatic lesions: computerized tomographic-guided versus endoscopic ultrasound-guided FNA. Cancer. 2006; 108: 180-5. PMid:16634071 http://dx.doi.org/10.1002/cncr.21912

[9] Naito Y, Okabe Y, Kawahara A, Taira T, Yamaguchi T, Abe H, Arikawa S, Nakayama M, Yasumoto M, Eriguchi N, Naito H, Kage M, Yano H. Guide to diagnosing primary pancreatic lymphoma, B-cell type: Immunocytochemistry improves the diagnostic accuracy of endoscopic ultrasonography-guided fine needle aspiration cytology. Diagn Cytophatology 2011 (in press).

[10] Jenssen C, Dietrich CF. Endoscopic ultrasound-guided fine needle aspiration biopsy, and biopsy in gastroenterology trucut - An overview. Best Pract Res Clin Gastroenterol. 2009; 23: 743-59. http://dx.doi.org/10.1016/j.bpg.2009.05.006

[11] Freeman C, Berg JW, Cutler SJ. Occurrence and prognosis of extranodal Lymphomas. Cancer. 1972; 29: 252-60. http://dx.doi.org/10.1002/1097-0142(197201)29:1<252::AID-CNCR2820290138>3.0.CO;2-\#

[12] Gospodarowicz MK, Sutcliffe SB, Brown TC, Chua T, Bush RS. Patterns of disease in localized extranodal Lymphomas. J Clin Oncol. 1987; 5: 875-80.

[13] Dragosics B, Bauer P, Radaszkiewicz T. Primary gastrointestinal non-Hodgkin's Lymphomas. A retrospective clinicopathologic study of 150 cases. Cancer. 1985; 55: 1060-73. http://dx.doi.org/10.1002/1097-0142(19850301)55:5<1060::AID-CNCR2820550523>3.0.CO;2-8

[14] Nakamura S, Akazawa K, Yao T, Tsuneyoshi M. A clinicopathologic study of 233 cases with Special reference to evaluation With The MIB-1 index. Cancer. 1995; 76: 1313-24. http://dx.doi.org/10.1002/1097-0142(19951015)76:8<1313::AID-CNCR2820760804>3.0.CO;2-1

[15] Koch P, Valle F, Berdel WE, Willich NA, Reers B, Hiddemann W, et al. Primary gastrointestinal non-Hodgkin's lymphoma: I. Anatomic and histologic distribution, clinical features, and survival data of 371 Patients registered in the German Multicenter Study GIT NHL 01/92. J Clin Oncol. 2001; 19: 3861-73.

[16] Caletti G, Fusaroli P Bocus P. Endoscopic ultrasonography. Digestion. 1998; 59: 509-29. PMid:9705536 http://dx.doi.org/10.1159/000007528

[17] Vetro C, Romano A, Chiarenza A, Conticello C, Donnarumma D, Gorgone A, Coppolino F, Palumbo GA, Bonanno G, Di Raimondo F. Endoscopic ultrasonography in gastric lymphomas: appraisal on reliability in long-term follow-up. Hematol Oncol 2011 (in press). PMCid:2980579

[18] Fischbach W, Goebeler-Kolve ME, Dragosics B, Greiner A, Stolte M. Long term outcome of Patients with gastric marginal zone B cell lymphoma of mucosa associated lymphoid tissue (MALT) Following Eradication exclusive Helicobacter pylori therapy: experience from a large prospective series. Gut. 2004; 53: 34-7. PMid:14684573 http://dx.doi.org/10.1136/gut.53.1.34

[19] Eck M, Schmausser B, Haas R, Greiner A, Czub S, Muller-Hermelink HK. MALT-type lymphoma of the stomach is Associated with Helicobacter pylori strains expressing the CagA protein. Gastroenterology. 1997; 112: 1482-6. http://dx.doi.org/10.1016/S0016-5085(97)70028-3

[20] Carlson SJ, Yokoo H, Vanagunas A. Progression of gastritis to monoclonal B-cell lymphoma with resolution and recurrence Following Eradication of Helicobacter pylori. Jama. 1996; 275: 937-9. http://dx.doi.org/10.1001/jama.1996.03530360047037

[21] Ruskone-Fourmestraux A, Dragosics B, Morgner A, Wotherspoon A, De Jong D. Paris staging system for primary gastrointestinal Lymphomas. Gut. 2003; 52: 912-3. http://dx.doi.org/10.1136/gut.52.6.912

[22] Schuder G, Hildebrandt U, Kreissler-Haag D, Seitz G, Feifel G. Role of endosonography in the surgical management of non-Hodgkin's lymphoma of the stomach. Endoscopy. 1993; 25: 509-12.

[23] Caletti G, Barbara L. Gastric lymphoma: difficult to diagnose, difficult to stage? Endoscopy. 1993; 25: 528-30. http://dx.doi.org/10.1055/s-2007-1010390

[24] Fischbach W, Goebeler-Kolve ME, Greiner A. Diagnostic accuracy of EUS in the local staging of primary gastric lymphoma: results of a prospective, Multicenter Study Comparing EUS with histopathologic stage. Gastrointest Endosc. 2002; 56: 696-700. http://dx.doi.org/10.1016/S0016-5107(02)70119-3

[25] Wiersema MJ, Gatzimos K, Nisi R, Wiersema LM. Staging of non-Hodgkin's gastric lymphoma with endosonography-guided fine-needle aspiration biopsy and flow cytometry. Gastrointest Endosc. 1996; 44: 734-6. http://dx.doi.org/10.1016/S0016-5107(96)70063-9

[26] Nobre-Leitao C, Lage P, Cravo M, Cabecadas J, Chaves P, Alberto-Santos A, et al. Gastric MALT lymphoma Treatment of Helicobacter pylori Eradication by: a study controlled by endoscopic ultrasonography. Am J Gastroenterol. 1998; 93: 732-6.

[27] The LM-Zahabi, Jamali FR, The H, II, Naja M, Salem Z, Shamseddine A, El-Saghir NS, Zaatari G, F Geara, Soweid AM. The value of EUS in Predicting the response of gastric mucosa-associated lymphoid tissue lymphoma to Helicobacter pylori Eradication. Gastrointest Endosc. 2007; 65: 89-96.

[28] Pavlick AC, Gerdes H, Portlock CS. Endoscopic ultrasound in the evaluation of gastric small lymphocytic mucosa-associated lymphoid tumors. J Clin Oncol. 1997; 15: 1761-6. 
[29] Levy M, Hammel P, Lamarque D, Marty O, Chaumette MT, Haioun C, et al Endoscopic ultrasonography for the initial staging and follow-up in Patients with low-grade gastric lymphoma of mucosa-associated lymphoid tissue Treated medically. Gastrointest Endosc. 1997; 46: 328-33. http://dx.doi.org/10.1016/S0016-5107(97)70120-2

[30] Puspok A, Raderer M, Chott A, B Dragosics, Gangl A, Schofl R. Endoscopic ultrasound in the follow up and response assessment of Patients with primary gastric lymphoma. Gut. 2002; 51: 691-4. http://dx.doi.org/10.1136/gut.51.5.691

[31] Di Raimondo F, Caruso L, Bonanno G, Naso P, Chiarenza A, Fiumara P, et al. Is endoscopic ultrasound Clinically useful for follow-up of gastric lymphoma? Ann Oncol. 2007; 18: 351-6. PMid:17065587 http://dx.doi.org/10.1093/annonc/mdl378

[32] Mehra M, Tamhane A, Eloubeidi MA. EUS-guided FNA Combined with flow cytometry in the diagnoses of Suspected or recurrent intrathoracic or retroperitoneal lymphoma. Gastrointest Endosc. 2005; 62: 508-13. PMid:16185962 http://dx.doi.org/10.1016/j.gie.2005.03.002

[33] Yasuda I, Tsurumi H, Omar S, Iwashita T, Kojima Y, Yamada T, et al. Endoscopic ultrasound-guided fine needle aspiration biopsy-for lymphadenopathy of unknown origin. Endoscopy. 2006; 38: 919-24. PMid:16981110 http://dx.doi.org/10.1055/s-2006-944665

[34] Freeman C, Berg J, Cutler SJ Occurrence and prognosis of extranodal Lymphomas of the pancreas. Cancer. 1972; 29: 252-60. http://dx.doi.org/10.1002/1097-0142(197201)29:1<252::AID-CNCR2820290138>3.0.CO;2-\#

[35] Behrns KE, Sarr MG, Strickler JG. Pancreatic lymphoma: is it a surgical disease? Pancreas. 1994; 9: 662-7. http://dx.doi.org/10.1097/00006676-199409000-00019

[36] Rossi ED, Larghi A, Verna EC, Martini M, Galasso D, Carnuccio A, et al. Endoscopic ultrasound-guided fine-needle aspiration cytologic with Liquid-based preparation in the diagnosis of primary pancreatic lymphoma. Pancreas. 2010; 39: $1299-302$. http://dx.doi.org/10.1097/MPA.0b013e3181dc694e

[37] Gimeno-Garcia AZ, Alonso MM, Garcia Castro C, Nicolas Perez D, Quintero E. [Primary pancreatic lymphoma by endoscopic ultrasound Diagnosed fine needle aspiration-guided biopsy]. Gastroenterol Hepatol. 2010; 33: 638-42. PMid:20932603 http://dx.doi.org/10.1016/j.gastrohep.2010.08.002

[38] Fritscher-Ravens A, Mylonaki M, Pantes A, Topalidis T, Thonke F, Swain P. Endoscopic ultrasound-guided biopsy for the diagnosis of focal lesions of the spleen. Am J Gastroenterol. 2003; 98: 1022-7. PMid:12809823

[39] Iwashita T, Yasuda I, Tsurumi H, Goto N, Nakashima M, Doi S, et al. Endoscopic ultrasound-guided fine needle aspiration biopsy for Splenic tumor: a case series. Endoscopy. 2009; 41: 179-82. PMid:19214901 http://dx.doi.org/10.1055/s-0028-1119474

[40] Eloubeidi MA, Varadarajulu S, Eltoum I, Jhala D, Chhieng DC, Jhala NC. Transgastric endoscopic ultrasound-guided fine needle aspiration biopsy, and flow cytometry of lymphoma of the spleen Suspected. Endoscopy. 2006; 38: 617-20. PMid:16685607 http://dx.doi.org/10.1055/s-2005-921111

[41] Meda BA, Buss DH, Woodruff RD, Cappellari JO, Rainer RO, Powell BL, et al. Diagnosis and subclassification of primary and recurrent lymphoma. The Usefulness and Limitations of fine-needle aspiration Combined cytomorphology and flow cytometry. Am J Clin Pathol. 2000; 113: 688-99. PMid:10800402

[42] Stacchini A, Carucci P, Pacchioni D, G Accinelli, Demurtas A, Aliberti S, et al. Diagnosis of deep-seated endoscopic ultrasound Lymphomas by fine needle aspiration-guided Combined with flow cytometry. Cytopathology. 2012; 23: 50-6. PMid:21219488 http://dx.doi.org/10.1111/j.1365-2303.2010.00842.x

[43] Young NA, Al-Saleem TI, Ehya H, Smith MR. Utilization of fine-needle aspiration cytology and flow cytometry in the diagnosis and subclassification of primary and recurrent lymphoma. Cancer. 1998; 84: 252-61. http://dx.doi.org/10.1002/(SICI)1097-0142(19980825)84:4<252::AID-CNCR11>3.0.CO;2-R

[44] Steinfort DP, Conron M, Tsui A, Pasricha SR, Renwick WE, Antippa P, et al. Endobronchial ultrasound-guided transbronchial needle aspiration for the evaluation of suspected lymphoma. J Thorac Oncol. 2010; 5: 804-9. http://dx.doi.org/10.1097/JTO.0b013e3181d873be

[45] Cafferty LL, Katz RL, Ordonez NG, Carrasco CH, Cabanillas FR. Fine needle aspiration diagnosis of intraabdominal and retroperitoneal Lymphomas by a morphologic and immunocytochemical approach. Cancer. 1990; 65: 72-7. http://dx.doi.org/10.1002/1097-0142(19900101)65:1<72::AID-CNCR2820650116>3.0.CO;2-Q

[46] Carrasco CH, Richli WR, Lawrence D, Katz RL, Wallace S. Fine needle aspiration biopsy in lymphoma. Radiol Clin North Am. 1990; 28: 879-83. PMid:2349393

[47] Cartagena N, Jr., Katz RL, Hirsch-Ginsberg C, Childs CC, Ordonez NG, Cabanillas F. Accuracy of diagnosis of malignant lymphoma by fine-needle aspiration Combining cytomorphology with immunocytochemistry and in selected cases, Southern blotting of aspirated cells: a tissue-controlled study of 86 Patients. Cytopathol Diagn. 1992; 8: 456-64. PMid:1396024 http://dx.doi.org/10.1002/dc.2840080506 
[48] Stelow EB, Lai R, Bardales RH, Mallery S, Linzie BM, Crary G, et al. Endoscopic ultrasound-guided fine-needle aspiration of lymph nodes: the Hennepin County Medical Center experience. Cytopathol Diagn. 2004; 30: 301-6. PMid:15108226 http://dx.doi.org/10.1002/dc.10405

[49] Ribeiro A, Vazquez-Sequeiros E, Wiersema LM, Wang KK, Clain JE, Wiersema MJ. EUS-guided fine-needle aspiration Combined with flow cytometry and immunocytochemistry in the diagnosis of lymphoma. Gastrointest Endosc. 2001 ; 53: 485-91. PMid:11275890 http://dx.doi.org/10.1067/mge.2001.112841

[50] Pugh JL, Jhala NC, Eloubeidi MA, Chhieng DC, IA Eltoum, Crowe DR, et al. Diagnosis of deep-seated lymphoma and leukemia by endoscopic ultrasound-guided fine needle aspiration biopsy-. Am J Clin Pathol. 2006; 125: 703-9. PMid:16707371 http://dx.doi.org/10.1309/9C8B78K0X27U77DC

[51] Miletic Z, Gizdic B, Stoos-Veic T, Kaic G, Novak NP, Tadic M, et al. Flow cytometric analysis of deep-seated lymph nodes. Anthropol Coll. 2010; 34: 377-80.

[52] Al-Haddad M, Savabi MS, Sherman S, McHenry L, Leblanc J, Cramer M, et al. Role of endoscopic ultrasound-guided fine-needle aspiration with flow cytometry to diagnose lymphoma: a single center experience. J Gastroenterol Hepatol. 2009; 24: $1826-33$. http://dx.doi.org/10.1111/j.1440-1746.2009.06005.x

[53] At Shanqeety O, Mourad WA. Diagnosis of peripheral T-cell lymphoma by fine-needle aspiration biopsy: a cytomorphologic and immunophenotypic approach. Cytopathol Diagn. 2000; 23: 375-9. http://dx.doi.org/10.1002/1097-0339(200012)23:6<375::AID-DC2>3.0.CO;2-1

[54] Young NA, Al-Saleem T. Diagnosis of lymphoma by fine-needle aspiration cytology using the revised European-American classification of lymphoid neoplasms. Cancer. 1999; 87: 325-45. http://dx.doi.org/10.1002/(SICI)1097-0142(19991225)87:6<325::AID-CNCR3>3.0.CO;2-W

[55] Yasuda I, Goto N, Tsurumi H, Nakashima M, Doi S, Iwashita T, et al. Endoscopic Ultrasound-Guided Fine Needle Aspiration Biopsy for Diagnosis of lymphoproliferative Disorders: Feasibility of Immunohistological, Flow cytometric, and Cytogenetic Assessments. Am J Gastroenterol. 2012; 107: 397-404 PMid:21989147 http://dx.doi.org/10.1038/ajg.2011.350

[56] Ribeiro A, Pereira D, Escalon MP, Goodman M, Byrne GE, Jr. EUS-guided biopsy for the diagnosis and classification of lymphoma. Gastrointest Endosc. 2010; 71: 851-5. PMid:20363431 http://dx.doi.org/10.1016/j.gie.2009.12.033

[57] Nakahara O, K Yamao, Bhatia V, Sawaki A, Mizuno N, Takagi T, et al. Usefulness of endoscopic ultrasound-guided fine needle aspiration (EUS-FNA) for undiagnosed intra-abdominal lymphadenopathy. J Gastroenterol. 2009; 44: 562-7. PMid:19360372 http://dx.doi.org/10.1007/s00535-009-0048-4

[58] Da Cunha Santos G, Ko HM, Geddie WR, Boerner SL, Lai SW, Have C, Kamel-Reid S, Bailey D. Targeted use of fluorescence in situ hybridization (FISH) in cytospin preparations: results of 298 fine needle aspirates of B-cell non-Hodgkin lymphoma. Cancer Cytopathol. 2010; 118: 250-8. PMid:20862704 http://dx.doi.org/10.1002/cncy.20098 